\title{
Modellalkotási kísérlet: a civil/nonprofit szervezetektôl a regionalizmusig
}

\section{Modelling experiments: from civil/nonprofit organisations to regionalism}

\author{
KÓBOR KRISZTINA
}

KULCSSZAVAK: civil/nonprofit szervezetek, társadalmi tőke, területi identitás, innováció, regionalizmus

ABSZTRAKT: A tanulmány egy olyan modell megalkotására tesz kísérletet, amely a civil/nonprofit szervezeteket kapcsolja össze három fogalmon keresztül a regionalizmussal. A fogalmakat a szakirodalomban leirt közös jellemzők bemutatásával, majd empirikus adatok vázolásával kapcsolom össze; két régió jellemzőit a modell alapján értelmezem a nyugat-dunántúli és észak-alföldi szociális és gyermekvédelmi célú civil/nonprofit szervezetek példáján.

A nyugat-dunántúli régió gazdasági szempontból sikeresebb régiónak számít, mint az Észak-alföldi régió. Talán ebből is adódik, hogy kevesebb a szociális és gyermekvédelmi célú civil/nonprofit szervezet, így a modell társadalmitőke- és területiidentitás-elemei is gyengébbek, helyettük inkább az individualizmus és a forprofit szervezetekkel való gyakoribb kooperáció a jellemzőbb. Az észak-alföldi régió tekintetében viszont a gazdasági tőke hiánya azł vonja maga után, hogy a hiányokat a társadalmi tőke konvertálásából kell megteremteni. Mindez komoly időráfordítást, jó kapcsolatteremtő és konfliktuskezelő készséget igényel, ugyanakkor azonban több kapcsolatot is, amelyekből több, bár kisebb léptékú és nem olyan összetett innováció, és összetartóbb közösségek származnak. Tehát a regionalizmus végbemenetele - ha gazdaságilag nem is, de - társadalmilag sikeresebb az észak-alföldi régióban, s a létrehozott modell is dinamikusabb.

KEYWORDS: civil/nonprofit organisations, social capital, regional identity, innovation, regionalism

ABSTRACT: In the present study I try to create a model which connects civil/nonprofit organisations with regionalism using different elements. The first element consists of common features collected from the pertinent literature. The second is a verification of the model using empirical data about civil/nonprofit social or child protection organisations in the Western Transdanubian and Northern Great Plain regions.

The model to describe civil/nonprofit organisations also links the elements of social capital, innovation and regional identity to regionalism. According to my model the five elements are interdependent and show a linear connection, with the civil/nonprofit organisations representing the starting point. The main focus is on these

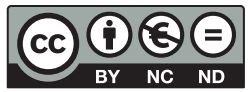


organisations and their relationships, because if the relationship based on social capital is strong and co-operations and bonding are strong, then this has an effect on the other three elements. If local relationships are an asset, territorial identity becomes stronger. Strong relationships transform into transfer channels, transporting more knowledge, information, support, emotions, experience and so forth. As a consequence, motivation for innovation is bigger, and there are more innovative possibilities, because knowledge and ideas accumulate. At the same time, those relationships and innovations generate new relationships in a steadily widening circle, which in turn generates the feeling of a stronger regional belonging.

Despite the fact that in the present study civil/nonprofit organisations provide the starting point and the goal is to arrive at regionalism, the empirical verification of the model demonstrate that its five elements have reciprocal effects on each other. They can even be mutually enhancing. It is conceivable or even likely, that this model can also be applied successfully in cases where the reciprocal effects are negative.

In conclusion, the elements of my model could be found to be linked in both regions, but the individual elements of the model have a different weight in each of the two regions. From the economic aspect, the Western Transdanubian Region is more successful than the Northern Great Plain Region. However, there are less social and child protection civil/nonprofit organisations in this region, therefore the social capital and territorial identity elements of the model are also weaker. Individualism and more frequent co-operation with commercially run organisations are more characteristic here. In the Northern Great Plain Region, deficiencies have to be compensated by sourcing social capital, which means using more energy, but gaining more relationships. These relationships result in more, though less complex, and slower innovations, and in stronger and more loyal communities. Therefore, the development of regionalism is more successful - if not from an economic point of view, but certainly socially -, and the elements of the model are also more dynamic.

\section{Bevezetés}

Jelen tanulmány célja az, hogy olyan elméleti modellt mutasson be, amely a civil/nonprofit szervezetek ${ }^{1}$ területi folyamatokban való részvételének módját tárja fel. A modell bemutatása - szakirodalmi értelmezések alapján - fogalmak összekapcsolásával történik, majd az elméleti modell értelmezésére térek ki, két régió szociális és gyermekvédelmi ${ }^{2}$ célú civil/nonprofit szervezeteit vizsgálom.

Az ebben a tanulmányban érvényesített megközelítés szerint a civil/nonprofit szervezetek az 1. ábrán ismertetett módon kapcsolódnak össze a társadalmi tőke, a (területi) identitás, az innováció és a regionalizmus fogalmaival és folyamataival. Az öt fogalom egy sorozatot alkot, lineáris összefüggést mutat, ahol megközelítésemben a civil/nonprofit szervezetek mint a társadalmi tőke „hardverei” (Szakál 2006) adják a kiindulópontot. Ezen szervezetek, valamint kapcsolataik, együttműködéseik (azaz a társadalmi tőke „szoftverei” (Szakál 2006)) jelentik a fő fókuszt, mivel ha a kapcsolati, társadalmi tőke erős, szorosak az együttmüködések és a kötések, akkor az hatással van a másik három tényezőre. A lokális kapcsolati tőke miatt erősebbé válik a területi identitás. A kap- 
1. ábra: A civil/nonprofit szervezetek, a társadalmi tőke, a területi identitás, az innováció és a regionalizmus kapcsolódó fogaskerekei The cogs of civil/nonprofit organizations, social capital, territorial identity, innovation and regionalism

Forrás: saját szerkesztés. ${ }^{3}$

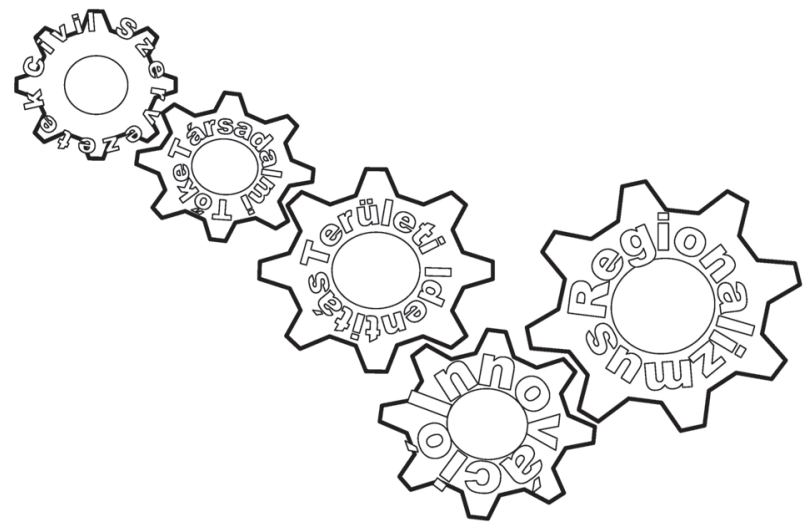

csolatok transzfercsatornákká válnak, ahol több tudás, információ, támogatás, érzelem, tapasztalat stb. áramlik, ezáltal nagyobb fokú innovációs hajlam és több újítási lehetőség adódik, mivel a tudások, ötletek kumulálódnak. Ugyanakkor a kapcsolatok és innovációk újabb kapcsolatokat hoznak magukkal, egyre táguló körben, ezáltal erősebb regionális összetartozás generálódik.

Annak ellenére, hogy jelen tanulmányban a civil/nonprofit szervezetek adják a kiindulópontot, és célom a regionalizmusig eljutni, a modell fogaskerekei azt szimbolizálják, hogy az öt fogalom oda-vissza hat egymásra, sőt egymás hatásait képesek felerősíteni. Bár jelen tanulmányban nincs módom a modell ellenkező irányban való mozgását kifejteni, feltételezésem az, hogy modellem ellenkező irányban is mozog(hat).

\section{Civil/nonprofit szervezetek bizalomteremtő szerepe, a modell elsó fogaskereke}

Beck (2003) az új modernitás egyik alapköveként fogalmazza meg az individualizációt mint értéket. Szerinte ez azzal is együtt jár, hogy az emberek egyre jobban belebonyolódnak a bizonytalanságba, ezért mindez magában foglalja új társadalmi kötődések keresését, tehát az egyének társadalmi problémáik leküzdése céljából koalíciókra kényszerülnek, amelyek nem osztálytól vagy rétegtől függően, hanem helyzettől és témától függően alakulnak ki, valójában célszövetségek formá- 
jában. A civil/nonprofit szervezetek a társadalom „termékei”, s fontos értéket teremtenek: a bizalom ${ }^{4}$ és a közösségi magatartás, szolidaritás ${ }^{5}$ értékét.

Utasi (2008) szerint az emberek nem elsősorban objektív gazdasági körülményektől függően érzik magukat boldognak, sokkal inkább valamilyen relációban gondolkodnak, s az életük akkor lesz leginkább rossz, „, ha hiányoznak vagy megszakadnak a társadalomba integráló közösségi kötelékeik" (Utasi 2008, 10.). A piacgazdasági versennyel kumulálódó hátrányokat lát a kapcsolatok terén: túlhajtott az egyéni verseny, elégtelen a szolidaritás, ezért szűkülnek az erős kapcsolatok, nőnek az egyenlőtlenségek, így szétszakadhat a társadalom, és

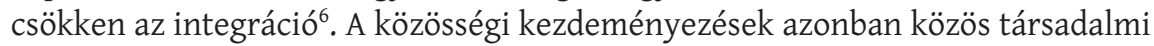
tőkét kovácsolni képes erőt képviselnek, s értékteremtő folyamatokként is értelmezhetők. A modernizálódó társadalomban ugyanis egyre nagyobb szükség van a civil/nonprofit szervezetekre, amelyek a lokális közösségekből táplálkoznak (Rechnitzer, Smahó 2005), nem csupán konkrét tevékenységük kapcsán, hanem annak érdekében is, hogy betöltsék a jóléti pluralizmus által elképzelt feladatukat, s intermedier területté tudjanak válni, ahol a gazdaság, állam és társadalom kapcsolatai találkoznak (Bartal 2005).

A modellben a civil/nonprofit szervezetek fogalma a kiindulópont. Ezen szervezetek ugyanis olyan jogi-szervezeti keretnek tekinthetök, amelyekben megjelenik a társadalmi tóke, a közösségi kötelékek és magatartás, az integráció, a bizalom és a szolidaritás.

\section{A civil/nonprofit tevékenység és a társadalmi tốke kapcsolata}

A civil/nonprofit szervezetek eloszlása Magyarországon nem egyenletes (Rechnitzer 1998, Nárai 2000, Bartal 2005), és a szervezetek száma nem tükrözi a társadalmi részvételre ${ }^{7}$ gyakorolt hatást. Ennek egyik oka, hogy nem minden szervezet folytat valódi tevékenységet, illetve nem mindegyik független állami szervezetektől avagy pártoktól, tehát a „szervezeti sűrűség” még nem kifejezője a közösségeket összetartó civil ethosznak (Miszlivetz 2001, 36.).

Coleman (1994, 1998), Putnam $(2000,2006)$ és Bourdieu (1997) szerint a magyarázat a fenti jelenségre a társadalmi tőke ${ }^{8}$ jelenségében és ezen belül a bizalom értékében rejtőzik, a gazdasági erő kevésbé befolyásoló tényező. Coleman (1994) megközelítése szerint a társadalmi tőke a társadalom szerkezetéből adódik. Ezzel szemben Bourdieu (1997) a csoporttagságot helyezi előtérbe mint erőforrást, és azt állítja, hogy a társadalmi tőkében anyagi és szimbolikus szempontok kapcsolódnak össze.

A legelterjedtebb meghatározás azonban az egyének közti kapcsolatok minőségére fókuszál (Putnam 2000). Eszerint a társadalmi tóke a szoros társadalmi hálónak, a civil/nonprofit szervezetek erösségének, a közösségi azonosságtudatnak és szolidaritásnak, valamint a bizalom és támogatás fokának következménye. Putnam 
szerint tehát a társadalmi tőkét három tényező határozza meg: egyesületi tagság, aktivitás és bizalom, valamint együttműködés, együttműködési készség.

A társas kapcsolatok és a támogatások tehát az emberek életminőségének, jól-létének (testi és lelki egészségének), ugyanakkor azonban a régió vagy egy adott terület jól-létének (társadalmi és gazdasági működőképességének) is fontos meghatározói. Tehát ha a civil/nonprofit szervezetek erősek, működésükkel megforgatják a társadalmi tőke kerekét, s ha az ezáltal megjelenő kapcsolatok és együttmüködések erősek és szorosak, akkor az hatással van a modellben felvázolt másik három tényezőre (területi identitásra, innovációra, regionalizmusra). Ebből következően modellemben a civil/nonprofit szervezetek és a társadalmi tőke fogaskerekei között a bizalom, a közösségi magatartás, az altruizmus, a szolidaritás és a reciprocitás az összekötő erö.

\section{A területi identitás elemének kapcsolódása a civil/nonprofit szervezetekhez és a társadalmi tókéhez}

Az általam kijelölt modellelemeket tovább bővítve jelenik meg az identitás fogalma, ezen belül a területi identitás. Az identitás fogalmában az egyéni és társadalmi meghatározottság együttesen van jelen; a tenni akarás, a bizalom és a hit elemeit foglalja magában, amely fogalmak a társadalmi tőkét és a civil/nonprofit szervezeteket tekintve is ismerősek.

A regionális identitás a térhasználat tudatos elemére (a térről szerzett ismeretekre, a gazdasági érdekekre, a társadalmi kapcsolatokra) épül, ami kognitív bázist jelent, ezen alapszik az identitás emocionális eleme, ami a térhasználatot otthonossá teszi. A regionális identitást növeli az etnokulturális jelleg, a politikai háttér és a gazdasági jelleg is (csakúgy, mint a társadalmi tőkét). Az egyének területi identitásában nem a terület maga, hanem a közösségi, emberi kapcsolatok a dominánsak, illetve az adott területi egységgel azonosítható társadalmi-gazdasági-kulturális folyamatok a meghatározóak. A területiség tehát csak foglalata a valóságnak, tartalmát a térről szerzett ismeretek, gazdasági érdekek, társadalmi kapcsolatok, kulturális folyamatok határozzák meg (Paasi 2002, 2003, Raagmaa 2002).

Bugovics (2007) vizsgálatai szerint a területi identitást elsődlegesen az egyén emberi kapcsolatai befolyásolják, illetve a csoporthoz tartozás élménye határozza meg, valamint az egzisztenciális-életminőségi tényezők. Azt is kijelenti, hogy a civil/nonprofit szféra jelenléte növeli a részvételt és az aktivitást, ami az identitás szempontjából is növelö tényezőt jelent.

Lukovics (2004) szerint pedig a régió és annak lakói közötti harmónia és egység meghatározza egy térség személyiségét, s az identitás a kulcseleme annak, hogy egy földrajzilag körülhatárolt terület valóban - társadalmi és politikai értelemben is - régióvá váljék. Rechnitzer (1999) puha tényezőknek nevezi a regionális miliő részeit, amelyek közé érti a - téma szempontjából fontos - társadalmi kapcsola- 
tokat, de ezen túl a településkörnyezetet, az életminőséget, a munkaerő minőségét, a kulturális szokásokat stb. is.

Összefoglalóan tehát megállapítható, hogy a területi identitás részben a civil/nonprofit szervezetek és az általuk képviselt lokális kapcsolati tőke miatt válik erősebbé. A modellben meghatározott fogaskerekek „olajozására” a csoporthoz tartozás és a közösségi kapcsolatok szolgálnak. A civil/nonprofit szféra tehát erősíti a társadalmi tőkét, aminek lokális elemei pedig (helyi, regionális kapcsolatok) az adott térben élők területi identitását támogatják az összetartozás, a közös térben élés és használat tudatán, megélésén keresztül.

\section{Az innováció fogalmának bekapcsolódása a modellbe}

Schumpeter (1911) klasszikus megközelítése szerint a termelés meglevő dolgok és erők kombinációját jelenti. Mást, vagy ugyanazt más módon termelni viszont annyit tesz, mint ezeket az erőket más módon kombinálni, s ezek az új kombinációk az innovációk. Az innovációs elméletek túlnyomó része a közgazdaságtanból származik, amelybe csak a '90-es évek közepétől kapcsolódtak be más tudományágak.

Így született meg többek között a szociológiai innovációelmélet (Rogers 1983, 1995), amely nem az innovációt létrehozó szervezetre, hanem az innováció elterjedésére fókuszál. Az innovációt ötletnek, viselkedésnek vagy tárgynak tekinti (kitágítva ezzel a klasszikus, schumpeteri definíciót), ami újnak tűnik a célcsoport számára. Ebben az elméletben tehát nem az emberek változnak, hanem az újítások maguk (Robinson 2009), s ez nem csupán kitágította a klasszikus innovációs megközelítést, hanem elterjedésével is foglalkozott.

Osborne (1998) a társadalmi szektor által megvalósított újításokra összpontosít. Tipológiájában a „hogyan” kérdése kerül előtérbe, így megkülönböztet:

1. hagyományos tevékenységeket (a szervezet speciális tevékenységet végez, de az újítás vagy változtatás bármely eleme nélkül);

2. fejlesztő tevékenységeket (a szervezet tevékenységében adalékként, járulékként jelenik meg a változás);

3. újító tevékenységeket (a szervezet megváltoztatja tevékenységének mintázatát és/vagy készségeit).

Osborne (2008) arra is felhívja a figyelmet, hogy a fentiek nem normatív kategóriák, csupán az innovációk azonosítására szolgálnak.

A modell szempontjából az innováció fogalma az előzőekhez a kielégitetlen szükségletek, a szociális kapcsolatokban való részvétel és az interakciók révén kapcsolódik. Olyan térségekben tehát, ahol erős a civil/nonprofit szféra, a társadalmi tőke és a területi identitás, ott nagyobb valószínűséggel ismerik fel a piac és az állam által ki nem elégített szükségleteket, s nagyobb valószínűséggel keresnek rájuk innovatív megoldásokat. A társadalmi részvételre és interakciókra ugyanis több lehetőség nyílik, a kapcsolatok kiterjedtebbek, ezáltal a transzfercsatornák több 
tudást, tapasztalatot, szükségletet tudnak közvetíteni, s több ötlet tud érkezni ezek kielégitésére is. Az innovatív megoldások a térség sajátos problémáira, szükségleteire adott egyéni válaszok, amelyek felhasználják a terület erőforrásait, s ezáltal a más területektől különbözőképpen szerveződő térség kialakulását segítik elő. Az innovációk tehát egyrészt a területen élők identitásérzését fokozzák - hiszen az újítás rájuk jellemző problémákat rájuk jellemző módon old meg -, másrészt pedig olyan törekvések, amelyek adott módon intézményesülő térséget idéznek elő. Ez utóbbi két jellemző kapcsolja az innováció fogaskerekét a regionalizmushoz.

\section{A modell utolsó eleme: a regionalizmus}

Lengyel Imre és Rechnitzer János (2004) Regionális gazdaságtan című könyvükben leírják, hogy a régió rugalmasan értelmezett fogalma nem pontatlanság következménye, hanem azé, hogy a gazdaság és a társadalom nagyon sokféle földrajzi közegben él együtt. A régiót három, egymással kapcsolatban álló folyamat hozza létre, nem a statisztikai tervezés elsődlegesen. Az egyik folyamat a regionalizáció, amelynek során a teret elkülönített egységekre bontjuk „top down” (államilag irányított) folyamatokkal, vagy „bottom up” (azaz települések önszerveződése) révén. A regionalizáció tehát vagy intézményi szinten irányított és szabályozott politikai folyamat, vagy belső jellemzők alapján történő térfelosztás, viszont mindkét esetben alapvetően horizontális térfelosztásról, a régió határainak kialakításáról van szó. A másik, ezt kiegészítő folyamat a regionalizálódás, amely esetben a térségi reálfolyamatok kényszerítik ki fokozatosan az új területi entitást, saját kohéziójuk alapján, mivel a társadalom és a gazdaság térségi szerveződése erős. A harmadik folyamat a regionalizmus, amely esetben a közös értékek, identitás, belső összetartozás alakítják át a teret régióvá. Freeman (1993) és Wagstaff (1999) szerint azonban a regionalizmus nem csupán a terület lakosságának közös identitásérzése, hanem az adott területen élők szélesebb körü autonómia megszerzésére irányuló törekvéseinek és cselekvésének összessége is.

Magyarországon a NUTS 2 szintủ régiók kialakítása szabályozott politikai folyamatokkal megtörtént, de a regionalizálódás és regionalizmus még várat magára, ezért a régiók nem tudnak megfelelően müködni. Az is elmondható, hogy a gyakorlati szakemberek általában nem látják világosan, hogy a civil/nonprofit szektor állapota és működése hatással van a fejlődésre egy adott térségben. Osváth (2005) szerint a legtöbb civil/nonprofit szervezettől nagyon távol áll a térségi gondolkodás, csak a saját szűk területükre koncentrálnak, és nem veszik észre, hogy tevékenységük révén a térség fejlődését ők is befolyásolják. Ez a fejlődés gazdasági értelemben könnyen mérhető. Ugyanakkor fontos felhívni a figyelmet arra, hogy a gazdasági mérőszámok önmagukban kevésbé alkalmasak a nonprofit szektor térségi szerepének mérésére és leírásá- 
ra, hiszen ezen szervezetek szerepe elsősorban nem gazdasági, hanem társadalmi. Így fordulhat elő, hogy egy erős civil háttérrel rendelkező régió gazdaságilag elmaradottabbnak bizonyul. ${ }^{9}$

\section{A modell elemeinek összekapcsolása}

A felállitott modellben tehát a civil/nonprofit szektor a társadalmi töke teremtésének fontos eszköze (a bizalom, a közösségi magatartás és a kapcsolatok formalizált keretének megteremtése által), s egyúttal lényeges identitásképző eszköz (a kognitív, kapcsolati elem működtetése, valamint az emocionális, csoporthoz való tartozás kifejezése által), illetve innovációs alap (az interakciók fórumának megteremtője és a kielégítetlen szükségletekre való reagálás gyors, adekvát eszköze), s ezen elemek által a regionalizmusra (a belső összetartozás kialakítására, az autonóm cselekvések és törekvések összességére) pozitív hatást tud gyakorolni. ${ }^{10}$

A modellben összekapcsolódó öt fogalom tehát egyszerű logikai ívet húz meg. Abban a térségben, ahol erős a civil/nonprofit szektor (jelen vannak a szervezetek, gazdálkodásuk biztos, megfelelő forrásokkal és humánerővel rendelkeznek, szolgáltatásokat nyújtanak, s ezáltal bevonják tevékenységükbe az informális szektort, széles körü és többirányú kapcsolatrendszert tartanak fenn), képes megforgatni a társadalmi tőke fogaskerekét (hiszen szorosak az együttmúködések és kötések, ezáltal bizalom, szolidaritás, közösségi magatartás, reciprocitás, altruizmus kerül előtérbe). Ez az erős kapcsolati tőke pedig azt eredményezi, hogy beindul a térséghez való tartozás érzése, erősödik az emocionális kötődés, a „jó itt élni" érzése, valamint a megteremtett szolgáltatások által tapasztalati, kognitív szinten is emelkedik az életminőség, amely elemek a területi identitás fogaskerekét lendítik mozgásba. Ez a három elem pedig azt eredményezi, hogy a kapcsolatok transzfercsatornákká válnak, ahol tudások, tapasztalatok, ötletek, igények áramlanak, s ez nagyobb fokú innovációs hajlamot és lehetőségeket teremt meg, bekapcsolva az innováció fogaskerekét is. Végül pedig ezek a hatások együttesen érik el azt, hogy a térségben megjelenjen az erősebb regionális összetartozás (az egyedi problémákra adott egyéni válaszok, azaz az innovációk kapcsán is), valamint az autonóm, a térség érdekében végzett cselekvés, ami a regionalizmus fogaskerekének mozgásba lendülését eredményezi.

\section{Két régió jellemzőinek értelmezése a modell elemein keresztül}

Az alábbiakban bemutatandó empirikus adatok a nyugat-dunántúli és észak-alföldi régióban, a szociális és gyermekvédelmi célú civil/nonprofit szervezetekre 
és kapcsolataikra irányuló kutatásom egy részét reprezentálják. Kutatásom során első lépésben KSH-, NAV- és bírósági adatokból adatbázist állítottam össze a két régió szociális és gyermekvédelmi célú civil/nonprofit szervezeteit tekintve. Az adatbázis összesen 2192 szervezetet sorol fel a két régióban, amelyeknek postai úton és interneten küldtem el az általam összeállított kérdőívet. Mintavétel nem történt, a teljes sokaság lekérdezésére törekedtem. A 2192 szervezet közül 104 szervezet küldte vissza a kérdőívet az észak-alföldi régióból és 108 szervezet a nyugat-dunántúliból. A kérdőívek elemzése után végül mindkét régióból 10-10 szervezetet választottam ki fókuszcsoportos interjú ${ }^{11}$ és 10-10 szervezetet interjú elkészítésére. A kutatás 2010-ben valósult meg a két említett régióban.

A modell öt eleméhez - mérésük, vizsgálatuk érdekében - különböző indikátorok tartoznak, ezeket az 1. táblázat foglalja össze.

A két régióban vizsgált összesen 212 szervezet indikátorokkal jelzett adatait a 2. táblázat foglalja össze.

A vizsgált szervezetek bevételei csaknem elérik a 1,5 milliárd forintot a két régiót tekintve, foglalkoztatottjaik száma összesen 4120 fo, ami átlagosan 4 fö egy szervezetnél Nyugat-Dunántúlon és 10 fó Észak-Alföldön. Céljaik és tevékenységük szerint kiemelt figyelmet fordítanak a családsegítésre, érdekvédelemre és közösségfejlesztésre mindkét régióban. Működésük által bizalmat ébresztenek az egyénekben és közösségeikben, példájukkal és szolgáltatásaikkal közösségi magatartásra biztatják őket. A Czike, Kuti (2006) féle társadalmi integráció értelmében pedig nem csupán szolgáltatásaikkal, de a társadalomhoz való kötődésükkel, beágyazottságukkal kétirányư ${ }^{12}$ integrációs tevékenységet végeznek.

A vizsgált szervezeteket tekintve Észak-Alföld pályázati bevételei (a pályázati rendszerbe épített ösztönzőknek ${ }^{13}$ köszönhetően) meghatározóbbak. A pályázati bevételek azonban csupán ellensúlyozzák a többi bevétel - fóként az adó 1\%-a, illetve az adományok tekintetében - alacsony mivoltát. Nyugat-Dunántúl ugyanakkor bevételeivel is bizonyítja gazdasági erejét.

Mindezek alapján kijelenthető, hogy bár mindkét régióban jelen vannak a vizsgált civil/nonprofit szervezetek - tehát megjelent az első fogaskerék -, a különbségek az észak-alföldi régióban működő szervezetek fogaskerekének mutatják nagyobb dinamikáját.

A társadalmi tóke szempontjából - amennyiben annak cselekvési kényszer, együttműködés (Coleman 1994) és mozgósítás (Fukuyama 1997) funkciójára gondolunk - az észak-alföldi régió társadalmitőke-fogaskerekének tapasztalható nagyobb dinamikája, hiszen több embert tudnak megmozgatni a foglalkoztatottsággal és az önkéntességet tekintve. Ebből következően a területi identitás - annak emocionális elemére gondolva - is jobb dinamikát mutat az észak-alföldi régióban, hiszen a modell ezen elemét is a foglalkoztatottság, önkéntesség, valamint a szervezetek jellemzőinek indikátoraival mértem. Ugyanakkor a területi identitás kognitív elemeire (szolgáltatások, munkahelyek) figyelemmel megállapítható, hogy a nyugat-dunántúli régió is mozgásba tudja lendíteni a maga területiidentitás-fogaskerekét, csak nem az identitás emocio- 
1. táblázat: A modell elemeihez rendelt indikátorok összefoglalása Summary of the indicators belonging to the model

\begin{tabular}{|c|c|c|}
\hline $\begin{array}{l}\text { A modell } \\
\text { elemei }\end{array}$ & Indikátor & $\begin{array}{c}\text { A modell elemének és az indikátornak } \\
\text { a kapcsolódása }\end{array}$ \\
\hline $\begin{array}{l}\text { civil/ } \\
\text { nonprofit } \\
\text { szerveze- } \\
\text { tek }\end{array}$ & $\begin{array}{l}\text { a szociális és gyermekvé- } \\
\text { delmi célú civil/nonprofit } \\
\text { szervezetek száma; } \\
\text { bevételeik; } \\
\text { céljaik és tevékenységük }\end{array}$ & $\begin{array}{l}\text { A modellben a civil/nonprofit szervezetek } \\
\text { fogalma a kiindulópont. Az indikátorral a } \\
\text { szervezetek jelenlétét, súlyát, illetve azt kell } \\
\text { bizonyitanom, hogy valódi tevékenységet } \\
\text { folytatnak a vizsgált térségekben. Mivel kuta- } \\
\text { tásom csupán a szociális és gyermekvédelmi } \\
\text { célú civil/nonprofit szervezetekre terjed ki, a } \\
\text { modell értelmezése nem lesz teljes körú. }\end{array}$ \\
\hline $\begin{array}{l}\text { társadalmi } \\
\text { tőke }\end{array}$ & $\begin{array}{l}\text { a foglalkoztatottak száma } \\
\text { és iskolai végzettsége; } \\
\text { önkéntesek egy szervezet- } \\
\text { re jutó átlaga és iskolai } \\
\text { végzettsége; } \\
\text { a szervezetek kapcsolatai } \\
\text { (ellátási szerződések, pá- } \\
\text { lyázati együttmúködések, } \\
\text { forprofit szervezetekkel } \\
\text { való kapcsolat); } \\
\text { a szervezetek saját megíté- } \\
\text { lése a kapcsolataik fontos- } \\
\text { sága tekintetében }\end{array}$ & $\begin{array}{l}\text { Kutatásomban az egyesületi tagságot, aktivi- } \\
\text { tást (amelyek a társadalmi tőkét képezik) a } \\
\text { foglalkoztatottak és az önkéntesek száma } \\
\text { reprezentálja, míg a bizalmat és az együtt- } \\
\text { működési készséget a szervezetek kapcsola- } \\
\text { tai és kapcsolataik fontossága indikátorokon } \\
\text { mérem. }\end{array}$ \\
\hline $\begin{array}{l}\text { területi } \\
\text { identitás }\end{array}$ & $\begin{array}{l}\text { a foglalkoztatottak száma } \\
\text { és iskolai végzettsége: } \\
\text { az önkéntesek egy szerve- } \\
\text { zetre jutó átlaga és iskolai } \\
\text { végzettsége; } \\
\text { a szervezetek száma, céljai } \\
\text { és tevékenysége }\end{array}$ & $\begin{array}{l}\text { A területi identitás tudatos és emocionális } \\
\text { elemét hivatottak a jelzett indikátorok mérni. } \\
\text { A tudatos elembőll a foglalkoztatottak szá- } \\
\text { mán keresztül határozom meg, hogy a mun- } \\
\text { kahelyek megteremtéséhez mennyiben járul } \\
\text { hozzá az alszektor. A tudatos elemhez tartozik } \\
\text { a térségben nyújott szolgáltatások minősége } \\
\text { is, amihez a vizsgált szervezetek tevékenysé- } \\
\text { ge tud hozzájárulni. Az emocionális elemből } \\
\text { a kapcsolatok a legfontosabbak, amelyek } \\
\text { számát az önkéntesek, illetve maguk a szer- } \\
\text { vezetek hivatottak bizonyítani. }\end{array}$ \\
\hline innováció & $\begin{array}{l}\text { az innovációk száma és } \\
\text { elterjedése }\end{array}$ & $\begin{array}{l}\text { Az innovációs adatok kérdőíves megkérde- } \\
\text { zésbőll származnak. Kérdőívem egy részében } \\
\text { a kitöltoókkel definiáltattam az innováció } \\
\text { fogalmát, majd a szervezet által megvalósi- } \\
\text { tott innovációkra kérdeztem, illetve arra, } \\
\text { hogy hány más szervezet és milyen jellegú } \\
\text { innovációját ismeri a kérdőívet kitöltő. }\end{array}$ \\
\hline $\begin{array}{l}\text { regiona- } \\
\text { lizmus }\end{array}$ & $\begin{array}{l}\text { a szervezetek száma; } \\
\text { saját megítélés a régió } \\
\text { múködéséhez való hozzá- } \\
\text { járulás tekintetében }\end{array}$ & $\begin{array}{l}\text { A regionalizmus belső összetartozási elemét } \\
\text { kutatásomban a szervezetek száma önma- } \\
\text { gában is reprezentálja, de a civil/nonprofit } \\
\text { szervezetek az autonómia megszerzésére } \\
\text { irányuló cselekvésnek is tekinthetők. A másik } \\
\text { indikátor a szervezetek saját bevallásán ala- } \\
\text { puló szubjektív mérés: kérdőívemben arra } \\
\text { voltam kiváncsi, hogy a szervezetekhez } \\
\text { mennyire áll közel a régió fogalma, hogyan } \\
\text { ítélik meg a térség fejlődéséhez való hozzá- } \\
\text { járulásukat. }\end{array}$ \\
\hline
\end{tabular}

Forrás: saját szerkesztés. 
2. táblázat: A modell elemeihez rendelt indikátorok adatainak összefoglalása (2010) Summary of the indicators' data belonging to the model (2010)

\begin{tabular}{|c|c|c|c|c|}
\hline \multirow{3}{*}{$\begin{array}{l}\text { A modell elemei } \\
\text { Civil/nonprofit } \\
\text { szervezetek }\end{array}$} & \multicolumn{2}{|c|}{ Indikátor } & \multirow{2}{*}{$\begin{array}{l}\text { Észak- } \\
\text { Alföld } \\
1347\end{array}$} & \multirow{2}{*}{$\begin{array}{l}\text { Nyugat- } \\
\text { Dunántúl } \\
845\end{array}$} \\
\hline & \multirow{2}{*}{$\begin{array}{l}\text { a szociális és gyermek- } \\
\text { védelmi célúak }\end{array}$} & száma az adatbázisban & & \\
\hline & & közül kérdőívet kitöltők & 104 & 108 \\
\hline & \multirow[t]{7}{*}{ bevételei, millió F† } & pályázatból & 444 & 185 \\
\hline & & $\begin{array}{l}\text { önkormányzati támoga- } \\
\text { tásként }\end{array}$ & 62 & 52 \\
\hline & & állami támogatásként & 92 & 85 \\
\hline & & az adó 1\%-aként & 66 & 165 \\
\hline & & adományként & 22 & 65 \\
\hline & & $\begin{array}{l}\text { egyéb (tagdíj, vállalko- } \\
\text { zási tevékenység) }\end{array}$ & 92 & 109 \\
\hline & & összesen & 825 & 622 \\
\hline & \multirow{3}{*}{$\begin{array}{l}\text { céljaik és tevékenysé- } \\
\text { gük relatív gyakorisága, } \\
\%\end{array}$} & családsegítés & 80 & 60 \\
\hline & & érdekvédelem & 60 & 30 \\
\hline & & közösségfejlesztés & 45 & 30 \\
\hline \multirow[t]{8}{*}{ Társadalmi tôke } & \multirow[t]{3}{*}{ a foglalkoztatottak } & $\begin{array}{l}\text { száma átlagosan, } \\
\text { fö/szervezet }\end{array}$ & 10 & 4 \\
\hline & & $\begin{array}{l}\text { iskolai végzettsége } 8 \\
\text { általános, \% }\end{array}$ & 10 & 6 \\
\hline & & $\begin{array}{l}\text { iskolai végzettsége } \\
\text { felsőfokú, \% }\end{array}$ & 26 & 28 \\
\hline & \multirow[t]{3}{*}{ az önkéntesek } & $\begin{array}{l}\text { száma átlagosan, } \\
\text { fő/szervezet }\end{array}$ & 18 & 9 \\
\hline & & $\begin{array}{l}\text { iskolai végzettsége } 8 \\
\text { általános, \% }\end{array}$ & 30 & 12 \\
\hline & & $\begin{array}{l}\text { Iskolai végzettsége } \\
\text { felsőfokú, \% }\end{array}$ & 20 & 26 \\
\hline & \multicolumn{2}{|c|}{$\begin{array}{l}\text { a szervezetek saját megítélése a kapcsolatok } \\
\text { fontossága tekintetében }\end{array}$} & \multicolumn{2}{|c|}{ lásd a 3. táblázatban! } \\
\hline & \multicolumn{2}{|c|}{$\begin{array}{l}\text { a szervezetek kapcsolatai (ellátási szerződések, } \\
\text { pályázati együttmúködések, } \\
\text { forprofit szervezetekkel való kapcsolat }\end{array}$} & \multicolumn{2}{|c|}{ lásd a 4. táblázatban! } \\
\hline Területi identitás & \multicolumn{2}{|c|}{$\begin{array}{l}\text { a foglalkoztatottak száma és iskolai végzettsége; } \\
\text { az önkéntesek egy szervezetre jutó átlaga és } \\
\text { iskolai végzettsége; } \\
\text { a szervezetek száma, céljai és tevékenysége }\end{array}$} & lásd a & htiekben! \\
\hline \multirow[t]{4}{*}{ Innováció } & \multirow[t]{4}{*}{$\begin{array}{l}\text { az innovációk száma és } \\
\text { elterjedése }\end{array}$} & $\begin{array}{l}\text { az összes feltárt innová- } \\
\text { ció aránya, \% }\end{array}$ & 55 & 45 \\
\hline & & $\begin{array}{l}\text { a válaszadó szervezetek } \\
\text { száma }\end{array}$ & 104 & 108 \\
\hline & & $\begin{array}{l}\text { közülük az innovációval } \\
\text { rendelkezők aránya, \% }\end{array}$ & 31 & 23 \\
\hline & & $\begin{array}{l}\text { az itt vizsgált szervezetek } \\
\text { közül azok aránya, } \\
\text { amelyeket mások inno- } \\
\text { vatívnak ismernek, \% }\end{array}$ & 15 & 23 \\
\hline \multirow[t]{3}{*}{ Regionalizmus } & \multicolumn{2}{|l|}{ a szervezetek száma } & \multicolumn{2}{|c|}{ lásd a fentiekben! } \\
\hline & \multirow[t]{2}{*}{$\begin{array}{l}\text { saját megítélés a régió } \\
\text { működéséhez való } \\
\text { hozzájárulás tekinteté- } \\
\text { ben }\end{array}$} & $\begin{array}{l}\text { a vizsgált szervezetek } \\
\text { közül azok aránya, } \\
\text { amelyek régiós hatáskö- } \\
\text { rünek minősítették a } \\
\text { tevékenységüket }\end{array}$ & & \\
\hline & & $\begin{array}{l}\text { relativ gyakoriság alapjár } \\
\text { szolgáltatásokkal járulnak } \\
\text { hez (50\%), illetve a civil/n } \\
\text { vel, valamint kapcsolatér }\end{array}$ & $\begin{array}{l}\text { eginkáb } \\
\text { lozzá a r } \\
\text { iprofit sz } \\
\text { éssel (4C }\end{array}$ & $\begin{array}{l}\text { kossági } \\
\text { śjlődésé- } \\
\text { bővítésé- } \\
\text { \%) }\end{array}$ \\
\hline
\end{tabular}

Forrás: saját szerkesztés. 
nális, hanem kognitív elemeivel. Nyugat-Dunántúlon ugyan kevesebben dolgoznak és önkénteskednek az alszektor szervezeteinél, viszont mind a foglalkoztatottak, mind az önkéntesek magasabb iskolai végzettséggel rendelkeznek észak-alföldi társaikénál.

Varga és Vercseg (1998) szerint a közösségfejlesztés, a közös cselekvés egyik meghatározó része az „elit” bevonása a tevékenységbe, s ez a bevonás a magasabb iskolai végzettségü foglalkoztatottakkal és önkéntesekkel a nyugat-dunántúli régióban megtörténik, tehát ez a régió is mozgásba tudja lendíteni - csak más hatóerőkkel - a maga területiidentitás-fogaskerekét.

A fentieket áttekintve azonban a társadalmi tőke bourdieu-i megközelítésére is hangsúlyt kell helyezni (1997), amely a társadalmi tőkét gyakorlatilag a kapcsolatokkal azonosítja. A 2. és 3. táblázat bemutatja, hogy a két régió szociális és gyermekvédelmi célú civil/nonprofit szervezetei esetében a vizsgált szervezetek mely kapcsolatokat ítéltek fontosnak, és mely szervezetekkel tartanak leggyakrabban kapcsolatot.

A kapcsolat fontossága mindkét régióban az informális szektorral kerül leginkább előtérbe (4,85 az átlag a két régió tekintetében), s a vizsgált szervezetek leggyakrabban a lakossággal tartanak kapcsolatot. Önkéntesek fogadása a szervezetek 67\%-ánál történik meg (4. táblázat).

3. táblázat: A kapcsolatok fontosságának átlaga a vizsgált szervezetek

és a két régió esetében (2010) (n=212) (1-5-ig terjedő skálán mérve)

Average of the contacts' importance in case of the examined organisations and the two regions (2010) $(n=212)$ (measured on a $1-5$ scale)

\begin{tabular}{lcc}
\hline \multicolumn{1}{c}{ A kapcsolat iránya } & Nyugat-Dunántúl & Észak-Alföld \\
\hline Lakosság, informális szektor & 5,0 & 4,7 \\
Önkormányzat & 4,5 & 4,4 \\
Más civil/nonprofit szervezet & 4,1 & 4,0 \\
Forprofit szervezet & 4,1 & 4,0 \\
\hline
\end{tabular}

Forrás: saját szerkesztés.

Az informális szektor mozgósítása (mennyiségi szempontból) az észak-alföldi régióban jobb, s szintén az észak-alföldi régió az, amely több ellátási szerződést realizál (16\%), illetve több pályázati együttműködést valósít meg más civil/nonprofit szervezettel (36\%). Annak ellenére, hogy a szervezetek saját bevallásuk szerint kevésbé aktívak a forprofit szektorral való kapcsolattartásban, mégis több bevételt tudnak ezekből a kapcsolatokból realizálni, mint a nyugatdunántúli régió szervezetei, ahol gyakoribb a gazdasági szervezetekkel való kapcsolattartás (40\%). Ezen elemek alapján úgy vélem, hogy a felállitott modellben a civil/nonprofit szervezetek és a társadalmi tóke fogaskereke Észak-Alföldön mutat nagyobb dinamikát, s ezáltal a területi identitás emocionális elemére hatva itt tudja jobban megforgatni a területi identitás fogaskerekét.

A két régióban két különböző tényező gyakorol hatást a társadalmi tőkére. Az észak-alföldi régióban a civil/nonprofit szektor nagysága, önmagában a szervezetek száma, illetve az általuk mozgósított egyének (foglalkoztatottak és 
4. táblázat: A kapcsolat gyakorisága a vizsgált szervezetek és a két régió esetében (2010) $(n=212)$

Prevalence of the contacts in case of the examined organisations and the two regions (2010) $(n=212)$

\begin{tabular}{|c|c|c|c|c|}
\hline $\begin{array}{l}\text { A kapcsolat } \\
\text { gyakorisága }\end{array}$ & Indikátor & $\begin{array}{l}\text { Nyugat- } \\
\text { Dunántúl }\end{array}$ & $\begin{array}{l}\text { Eszak- } \\
\text { Alföld }\end{array}$ & Összesen \\
\hline $\begin{array}{l}\text { A lakossággal, az } \\
\text { informális szektorral }\end{array}$ & $\begin{array}{l}\text { Önkéntesek megjelenése a } \\
\text { szervezeteknél }\end{array}$ & 66 & 67 & 67 \\
\hline \multirow[t]{2}{*}{ Az önkormányzattal } & ellátási szerződések gyakorisága & 6,5 & 16 & 11 \\
\hline & $\begin{array}{l}\text { civil referenssel fenntartott } \\
\text { kapcsolat }\end{array}$ & 30 & 27 & 28 \\
\hline $\begin{array}{l}\text { Más civil/nonprofit } \\
\text { szervezettel }\end{array}$ & $\begin{array}{l}\text { más civil/nonprofit szervezettel } \\
\text { való kapcsolat, pályázati } \\
\text { együttműködés formájában }\end{array}$ & 19 & 36 & 28 \\
\hline Forprofit szervezettel & $\begin{array}{l}\text { forprofit szervezettel fenntartott } \\
\text { kapcsolat }\end{array}$ & 40 & 26 & 33 \\
\hline
\end{tabular}

Forrás: saját szerkesztés.

önkéntesek) száma az a hatás, ami mozgásba hozza a második fogaskereket. A nyugat-dunántúli régióban ugyanakkor a szervezetek a gazdasági tőke tekintetében biztosabb lábakon állnak, nem hagyatkoznak oly sokat a bizonytalan pályázati bevételekre. Ez a két különböző hatás (a mozgósított egyének és az anyagi fenntarthatóság) azonban a két régióban eltérő befolyást gyakorol a további fogaskerekekre is. Mivel Észak-Alföldön erősebb a kapcsolati tőke, könnyebben indul be a területi identitás emocionális eleme, ami azt is jelenti, hogy az innovációk létrehozásának alapját adó szükségletek hamarabb válnak köztudottá. Ezzel szemben a nyugat-dunántúli régióban a kevesebb szervezet, viszont erősebb gazdasági háttér a területi identitás kognitív elemére (a szolgáltatásokra, a munkahelyekre) képes hatni, s ez az innovációk számára is erősebb anyagi hátteret teremt.

Az innováció fogaskereke tekintetében tehát a minőség és mennyiség eleme versenyez egymással, hiszen az iskolai végzettség, ami mind az önkénteseket, mind a foglalkoztatottakat tekintve a nyugat-dunántúli régióban magasabb, elvileg nagyobb tájékozottságot adhat, s ebből következően nagyobb kreativitást. Ugyanakkor a mennyiség - ami az észak-alföldi régióban meghatározóbb - egyrészt több ötletből való válogatást tesz lehetővé, másrészt pedig mivel a több ember jobban köti a társadalomhoz a szervezeteket, több kielégítetlen szükséglet juthat a szervezetek tudomására, ami jelen esetben az innovációs tevékenység alapja.

Az észak-alföldi régióban a válaszadók beszámolójára alapozva elmondható, hogy több innovációt mutatnak fel a vizsgált szervezetek. Ezzel szemben az innovációk terjedése a nyugat-dunántúli régióban jobb. Modellem szempontjából viszont mindez azt jelenti, hogy az innováció fogaskereke - mivel nagyobb súllyal esik a latba, hogy ne elszigetelt újításról legyen szó, amit senki sem tud használni - a nyugat-dunántúli szervezetek esetében talán „sebesebben” forog. 
Végül pedig ezek a hatások együttesen érik el azt, hogy a térségben megjelenjen az erősebb regionális összetartozás (az egyedi problémákra adott egyéni válaszok, azaz az innovációk kapcsán is), valamint az autonóm, a térség érdekében végzett cselekvés, ami a regionalizmus fogaskerekének mozgásba lendülését eredményezi mindkét régióban.

A megkérdezett hatások közül (munkahely, értékteremtés, érdekvédelem, állami feladatok átvétele, szolgáltatások nyújtása, a civil/nonprofit szektor fejlesztése) szinte mindegyikben az észak-alföldi régió vizsgált szervezetei ítélték nagyobbnak hozzájárulásukat a régió sikeres müködéséhez. Úgy tűnik tehát, hogy az elemeknek, amelyek a modellre ható tényezókként azonosithatók (a szervezetek száma, gazdasági súlya, az informális szektort mozgósító ereje, kapcsolatok létezése, erőssége, módja, rendszeressége, az innovációk száma és elterjedése) mennyiségi oldala, nem pedig minőségi meghatározottsága esik nagyobb súllyal a latba, ezek jobban befolyásolják tehát a modell dinamikáját.

\section{Összegzés}

Összefoglalóan elmondható, hogy a két régió mindegyikében megtalálhatók a fenti, általam felállított modell elemei, és azok egymáshoz kapcsolódnak. Ugyanakkor a régiók nem egyformák az elemek súlyát tekintve.

A nyugat-dunántúli régió gazdasági szempontból sikeresebbnek számít (általánosságban a foglalkoztatottság aránya miatt, a vizsgált szervezeteknél az adó 1\%-ából származó bevétel, illetve az adományokból származó bevétel is ezt bizonyítja), mint az észak-alföldi régió. Talán ebből is adódik, hogy kevesebb a szociális és gyermekvédelmi célú civil/nonprofit szervezet, így a modell társadalmitőkeés területiidentitás-elemei is gyengébbek, helyettük inkább az individualizmus és a forprofit szervezetekkel való gyakoribb kooperáció a jellemzőbb. Az egyénnek (Beck (2003) megközelítésénél maradva) kevesebb társadalmi problémát kell megoldania, ezáltal civil/nonprofit szervezetek - főleg szociális és gyermekvédelmi célú közösségek létrehozására is kevesebb motivációt érez. Ezzel párhuzamosan viszont több gazdasági tőkét tud mozgósítani egy-egy szervezet, ezért a társadalmi tőke gazdasági tőkévé való konvertálásába kevesebb energiát kell fektetni, s komplexebb, nagyobb volumenű innovációkat tud létrehozni. Ezzel szemben az észak-alföldi régió nem rendelkezik ezekkel az előnyökkel, tehát az ott élőknek több, a területi identitást és társadalmi tőkét mozgósító civil/nonprofit szervezetet kell létrehozniuk, súlyosabb problémákat kell megoldaniuk több rendezvénnyel, valamint az alapvetőbb szükségleteket kielégíteni képes szolgáltatásokkal. Az észak-alföldi régió tekintetében viszont a gazdasági tőke hiánya azt vonja maga után, hogy a hiányokat a társadalmi tőke konvertálásából kell megteremteni. Mindez komoly időráfordítást, jó kapcsolatteremtő- és konfliktuskezelő készséget igényel, ugyanakkor azonban több kapcsolatot is, amelyekből több (bár 
kisebb léptékű és kevésbé összetett) innováció jön létre, és összetartóbb közösségek származnak. Tehát a regionalizmus végbemenetele - ha gazdaságilag nem is, de társadalmilag sikeresebb az észak-alföldi régióban, s a létrehozott modell is dinamikusabb.

\section{Jegyzetek}

1 A fogalomhasználat változó, s legtöbbször szinonimaként használják a civil, nonprofit, NGO stb. kifejezéseket. Nárai (2007) dolgozatában tisztázni próbálja a zavaros fogalomhasználatot, s a civil társadalom fogalom keretén belül definiálja a társadalmi önszerveződéseket (=civil szféra), amibe tartozónak tekinti a nonprofit szektort. Nárai megközelítése szerint a nonprofit szektor magában foglalja a civil nonprofit szektort és az államközeli nonprofitokat. Jelen tanulmányban - a terminológiai vitákat elkerülve - törekszem a civil/nonprofit kifejezés használatára, amelyen elsősorban a civil nonprofit szektort értem, nem az államközeli nonprofitokat. Meggyőződésem szerint a regionalizmusban az alulról építkező civil szervezetek töltenek be nagyobb szerepet, amelyek empirikus vizsgálata ugyanakkor a bejegyzett (nonprofit) szervezeteken keresztül válik elsősorban lehetővé. A civil/nonprofit kifejezés használatával tehát azt hangsúlyozom, hogy az alulról építkező, de bejegyzett szervezetek adják a fogalomhasználat kiindulópontját.

2 A legtöbb megközelítés (lásd pl. a nonprofit szervezetek KSH általi besorolását) a gyermekvédelmet és a gyermekvédelmi célú szervezetek munkáját a szociális szféra tevékenységeihez sorolja. Jelen tanulmányban azonban szükséges a két fogalom elkülönítése, ezzel is kiemelve, hogy más célcsoporttal foglalkozik, más jogszabály adta eszközökkel operál, és különböző jogszabályok (az 1993. évi III. törvény és az 1997. évi XXXI. törvény) alapján müködik a szociális és gyermekvédelmi tevékenység ma Magyarországon. Néhány szakembernek bizonyára az is zavaró lesz, hogy a fogalomhasználatban nem válik ketté a gyermekjóléti és a gyermekvédelmi kifejezés, ahogy ezt az 1997. évi XXXI. törvény megteszi. Ennek oka a fogalomhasználat egyszerüsítése, illetve az, hogy az imént hivatkozott jogszabály is a gyermekek védelméről szól, ezért a törvény címében érvényesített fogalmat használom.

3 Hugh Barr az interprofesszionális szemlélet megjelenítésekor, 2007-ben, a European Social Work Symposiumon használta az 1. ábrán megjelenő fogaskerékelemeket egy másik modell illusztrálására. Köszönet neki az ötletért és a fogaskerékelemekért.

4 Fukuyama (1997) megközelítésében a bizalom az együttműködés és a mozgósítás mellett a társadalmi tőkét képző elemek egyike. Utasi $(2000,2008)$ konkrét definíciója szerint a bizalom valamilyen körülmény pozitív alakulásába vetett hit, ami - Fukuyamát igazolva - egyúttal a kapcsolatokban termelődő kötőelem is.

5 Szolidaritás: közös, kölcsönös kötelességvállalás, ami a bizalom mellett kötőerőként is szerepel egyének, csoportok, szervezetek és a társadalom kapcsolataiban.

6 Társadalmi integráció: egyetértve Castel $(1993,1998)$ és Utasi $(2000)$ megközelítésével - a szektorok egymással való kapcsolatán, együttműködésén alapuló kohézió. Czike és Kuti (2006) megfogalmazásában pedig közösségképző erő, amely orvosolja a különböző társadalmi csoportok közti egyenlőtlenségeket.

7 Jelen tanulmányban nem foglalkozom a széles szakirodalmi bázissal bíró (Marshall 1950, Nizák, Péterfi 2005, Westholme, Montero, Deth 2007) társadalmi részvétellel, csupán definícióját adom meg: olyan közvetlen formája a közösségi tagságnak, amely lojalitáson és közös akaraton alapul, s melynek formalizált megjelenése a civil/nonprofit szervezet. Nizák és Péterfi konkrétabb megfogalmazása szerint pedig személyek és csoportok magatartása, tevékenységei, amelyeket azért végeznek, hogy befolyásolják és alakítsák az életüket meghatározó intézmények müködését. Ezen szerzők egyetértenek abban is, hogy a civil/nonprofit szervezetek száma nem egyenlő a társadalmi részvétellel. 
8 Sebestény (2011) egyenesen a „civil tőke” fogalmát használja, modellem első két elemét összevonva. Tézise szerint, Colemanra alapozva, a civil tőke az ötödik tőkefajta a pénz, a tárgyi, az emberi és a társadalmi (kapcsolati) tőke mellett. A civil tőke esetében a tagok közti viszonyrendszer befolyásolja, ösztönzi a közös cél érdekében a cselekvést. A személyek ismeretségéből, egyéni képességek begyüjtéséből alaptőke keletkezik, s erre alapozva gerjeszti a szervezet programja a cselekvési kényszert. Szakál (2008) pedig egyik munkájában egyenesen módszertani egyszerüsítést tesz a civil/nonprofit szervezetek és a társadalmi tőke között, ugyanannak a jelenségnek tartva őket.

9 Ezzel a jelenséggel találkozunk a tanulmány empirikus részében, az észak-alföldi és a nyugatdunántúli régió példáján keresztül.

10 A regionalizálódás folyamatához is fontos hozzájárulást tehetnek a civil/nonprofit szervezetek (pl. a területfejlesztő, településfejlesztő célúak), azonban tanulmányomnak nem célja ezen szervezetek vizsgálata. Ezen szervezetekről kiváló vizsgálatot folytatott le Reisinger (2010).

11 A fókuszcsoportos interjúval célom volt, hogy egy-egy szervezet általa legfontosabbnak tekintett kapcsolati partnereinek képviselőit ültessem egy asztalhoz, és vizsgáljam. A fókuszcsoportos interjúval járó szervezést nem minden, általam kiválasztott szervezet tudta vállalni, ezért a többi szervezet képviselőjével interjút készítettem. A szociális és gyermekvédelmi célú civil/nonprofit szervezetek azért kerültek kiválasztásra, mert alapvégzettségem szociális munkás, és kilenc évig dolgoztam gyermekvédelmi civil szervezetnél.

12 Egyrészt a hátrányos helyzetű, leszakadó rétegeket a casteli értelmezésben kapcsolatokon és munkalehetőségeken keresztül kötik (Kozma 2003) a társadalomhoz, másrészt pedig az adományozáson és az önkéntes munkán keresztül a társadalom közép- és felső rétegeit közelítik a leszakadó rétegekhez.

13 Több pályázat kiírása, illetve a pályázati előírások - hátrányos helyzetű térségek preferálása célzottá alakítása.

\section{Irodalom}

Bartal A. M. (2005): Nonprofit elméletek, modellek, trendek. Századvég Kiadó, Budapest

Beck, U. (2003): A kockázattársadalom. Andorka Rudolf Társadalomtudományi Társaság, Századvég Kiadó, Budapest

Bourdieu, P. (1997): Gazdasági tőke, kulturális tőke, társadalmi tőke. In: Angelusz, R. (szerk.): A társadalmi rétegződés komponensei, Válogatott tanulmányok. Új Mandátum Könyvkiadó, Budapest, 156-178.

Bugovics Z. (2007): Társadalom, identitás, területfejlesztés. L'Harmattan Kiadó, Budapest

Castel, R. (1993): A nélkülözéstől a kivetettségig - a „kiilleszkedés” pokoljárása. ESÉLY, 3., 3-23.

Castel, R. (1998): Az új szociális kérdés. ESÉLY, 2., 3-19.

Coleman, J. (1994): Társadalmi tőke. In: Lengyel Gy., Szántó Z. (szerk.): A gazdasági élet szociológiája. Aula, Budapest, 99-127.

Coleman, J. (1998): Társadalmi tőke az emberi tőke termelésében. In: Lengyel Gy., Szántó Z. (szerk.): Tókefajták. Aula, Budapest, 11-14.

Czike K., Kuti É. (2006): Önkéntesség, jótékonyság, társadalmi integráció. Nonprofit Kutatócsoport és Önkéntes Központ Alapítvány, Budapest

Fukuyama, F. (1997): Bizalom. Európa Könyvkiadó, Budapest

Freeman, O. (1993): Régionalisme et Régionalisation en Europe. In: Slugocki J. (ed.): Regionalism in Europe: Traditions and New Trends. European Centre for Regional and Ethnic Studies, Bydgoszcz, European Cultural Centre, Geneva

Kozma J. (2003): A szegénység pszichológiai vonatkozásai. ESÉLY, 2., 15-30.

Lengyel I., Rechnitzer J. (2004): Regionális gazdaságtan. Dialóg Campus Kiadó, Budapest-Pécs 
Lukovics M. (2004): A regionális identitás szerepe a regionális gazdaságfejlesztésben. In: Czagány L., Garai L. (szerk.): A szociális identitás, az információ és a piac. SZTE Gazdaságtudományi Kar Közleményei, JATE Press, Szeged, 214-228.

Miszlivetz F. (2001): Közép-Európa a kapuk elótt. Savaria University Press, Szombathely

Nárai M. (2007): A nonprofit szervezetek helye és szerepe a helyi társadalmak életében. Doktori értekezés, Budapest

Nizák P., Péterfi F. (2005): A közösségi részvétel - társadalmi és hatalmi beágyazottság. Nonprofit Szektor Analízis, Budapest

Osborne, S. (1998): Naming the Beast. Defining and Classifying Service Innovations in Social Policy. Human Relations, 9., 1133-1154.

Osborne, S. et al. (2008): The Once and Future Pioneers? The Innovative Capacity of Voluntary Organisations and the Provision of Public Services: a Longitudinal Approach. Public Management, Review on 'Innovation in Public Services', 1. - January 2008

Osváth L. (2005): A civil szervezetek térségi együttmüködései Magyarországon. Országos Civil Érdekképviseletért Egyesület, Budapest

Paasi, A. (2002): Regional Transformation in the European Context: Notes on Regions, Boundaries and Identity. Space and Polity, 2., 197-201.

Paasi, A. (2003): Region and Place: regional identity in question. Progress in Human Geography, 4., 475-485.

Putnam, R. (2000): Bowling Alone. Simon and Schuster, New York

Putnam, R. (2006): A prosperáló közösség. A társadalmi tőke és a közélet. Civil Fórum, Kolozsvár, 2., $11-17$.

Raagmaa, G. (2002): Regional Identity in Regional Development and Planning. European Planning Studies, 1., 55-76.

Rechnitzer J. (1998): Nonprofit szervezetek területi szerkezete. In: Magyarország évtizedkönyve 1988-1998, 1. kötet. Demokrácia Kutatások Magyar Központja Alapítvány, Budapest, 539-553.

Rechnitzer J. (1999): Területi stratégiák. Dialóg Campus, Pécs

Rechnitzer J., Smahó M. (2005): A humán erőforrások regionális sajátosságai az átmenetben. MTA Közgazdaságtudományi Intézet, Budapest

Reisinger A. (2010): Társadalmi részvétel a helyi fejlesztéspolitikában - különös tekintettel a civil/nonprofit szervezetek szerepére. Doktori értekezés, Győr

Robinson, L. (2009): A Summary of Diffusion of Innovations. http://www.enablingchange.com.au Letöltve: 2010.12.12.

Rogers, E. (1983): Diffusion of Innovations. The Free Press, New York

Schumpeter, J. A. (1911): Theory of Economic Development/Theorie der Wirtschaftlichen Entwicklung. Duncker\&Humblot, Berlin, 1987 (7)

Sebestény I. (2011): A helyi önkormányzatok és a civil szervezetek együttmüködésének dimenziói, a kapcsolatrendszer funkcionális elemzésének és mérésének lehetőségei. Doktori értekezés, Pécs

Szakál Gy. (2006): A civil szektor szerepe a társadalmi tóke képződésében. MTA Politikai Tudományok Intézete Etnoregionális és Antropológiai Kutatóközpont, Budapest

Szakál Gy. (2008): Társadalmi tőke - sikeres és sikertelen társadalom. In: Szretykó Gy., Vezér M. (szerk.): A nonprofit szektor és az egészségügyi, szociális szolgáltatások; A nonprofit szervezetek szociológiai és társadalom-gazdaságtani problémái. Comenius Kft., Pécs, 15-41.

Utasi Á. (2000): A társadalmi integráció és szolidaritás alapjai: a bizalmas kapcsolatok. http//www.szazadveg.hu/files/kiadoarchivum24utasi.pdf Letöltve: 2010.12. 20.

Utasi Á. (2008): Éltető kapcsolatok. Új Mandátum Könyvkiadó, Budapest

Varga A. T., Vercseg I. (1998): Közösségfejlesztés. Magyar Művelődési Intézet, Budapest

Wagstaff, P. (1999): Regions, Nations, Identities. In: Wagstaff, P. (szerk.): Regionalism in the European Union. Intellect, Exeter, Portland

Westholm, A., Montero, J. R., Deth, van J. W. (2007): Introduction - Citizenship, involvement, and democracy in Europe. In: Westholm, A., Montero, J. R., Deth, van J. W. (eds.): Citizenship and Involvement in European Democracies - A comparative analysis. Routledge, 1-32.

1993. évi III. törvény a szociális igazgatásról és szociális ellátásokról

1997. évi XXXI. törvény a gyermekek védelméről és a gyámügyi igazgatásról 